\title{
Piassava Fiber: A Novel Reinforcement for Cement-Based Matrix Composites
}

\section{Fibra de piaçava: um novo reforço para compósitos de matriz à base de cimento}

\author{
Afonso R. G. Azevedo ${ }^{1}$, Thuany E. S. Lima ${ }^{1}$, Noan T. Simonassi ${ }^{1}$, Matheus P. Ribeiro*2, Fabio \\ C. Garcia Filho ${ }^{2}$, Sergio N. Monteiro ${ }^{2}$
}

\begin{abstract}
The addition of 2 and $5 \mathrm{wt} \%$ of piassava fiber, a natural lignocellulosic fiber extracted from a Brazilian palm tree botanically named Attallea funifera, into cement-based matrix composites was investigated. Both alkali-treated piassava fibers by $\mathrm{NaOH}$ and non-treated fibers were embedded in Portland cement, lime, and sand to fabricate mortars intended for civil construction. The non-aged fresh mortars were tested for paste consistency, water retention, and relative volume of incorporated air. Preliminary results showed that the addition of $\mathrm{NaOH}$-treated piassava slightly increased the water retention while decreasing the incorporated air content. Together with these preliminary results, the comparatively low density of the piassava fiber allows the fabrication of novel cement-based composite with the potential to be used as mortar in building construction.
\end{abstract}

Keywords: Piassava fiber; Cement-based composite; Fresh properties; Mortar.

\section{RESUMO}

A adição de 2 e $5 \%$ em peso de fibra de piaçava, uma fibra natural lignocelulósica extraída da palmeira brasileira chamada botanicamente de Attallea funifera, em compósitos de matriz cimentícia foi investigada. Tanto as fibras submetidas a tratamento alcalino com $\mathrm{NaOH}$ quanto as fibras não tratadas foram embutidas em cimento Portland, cal e areia para a fabricação de argamassas destinadas à construção civil. As argamassas frescas não envelhecidas foram testadas quanto à consistência da pasta, retenção de água e volume relativo de ar incorporado. Os resultados preliminares mostraram que a adição de piaçava tratada com $\mathrm{NaOH}$ aumentou ligeiramente a retenção de água enquanto diminuiu o teor de ar incorporado. Juntamente com esses resultados preliminares, a densidade comparativamente baixa da fibra de piaçava permite a fabricação de um novo compósito à base de cimento com potencial para ser usado como argamassa na construção civil.

Keywords: Fibra de piaçava; Compósito à base de cimento; Propriedades no estado fresco; Argamassa.

\section{INTRODUCTION}

${ }_{1}^{1}$ Advanced Materials Laboratory, State University of the Northern Rio de Janeiro - UENF. Av.

Alberto Lamego 2000, Campos dos Goytacazes, RJ, Brazil, 28013-602.

2 Department of Materials Science, Military Institute of Engineering - IME. Praça General Tibúrcio

80, Rio de Janeiro, RJ, Brazil, 22290-270

*E-mail: matheuspribeiro@ime.eb.br 
Os The past decades corresponding to the transition from the 20th to the present 21st century witnessed a surge on research works (AISYAH et al., 2021; FARUK et al., 2014; KARIMAH et al., 2021; MONTEIRO et al., 2009, 2011; PICKERING; EFENDY; LE, 2016; SANJAY et al., 2018; THYAVIHALLI GIRIJAPPA et al., 2019; VIGNESHWARAN et al., 2020; ZHANG et al., 2020) and advanced applications (BENZAIT; TRABZON, 2018; DUNNE et al., 2016; KUMAR et al., 2019; LI et al., 2020; POTLURI; CHAITANYA KRISHNA, 2020) of polymer matrix composites reinforced with natural lignocellulosic fibers (NLFs). Luz et al. (LUZ et al., 2020) reported exponential growth in world documents related to "Natural fiber and composite", illustrated in Figure 1, which shows more than one thousand publications per year beyond 2020 along the current decade.

Figure 1 - Publications per year for "Natural fiber and composite" according to Scopus database.

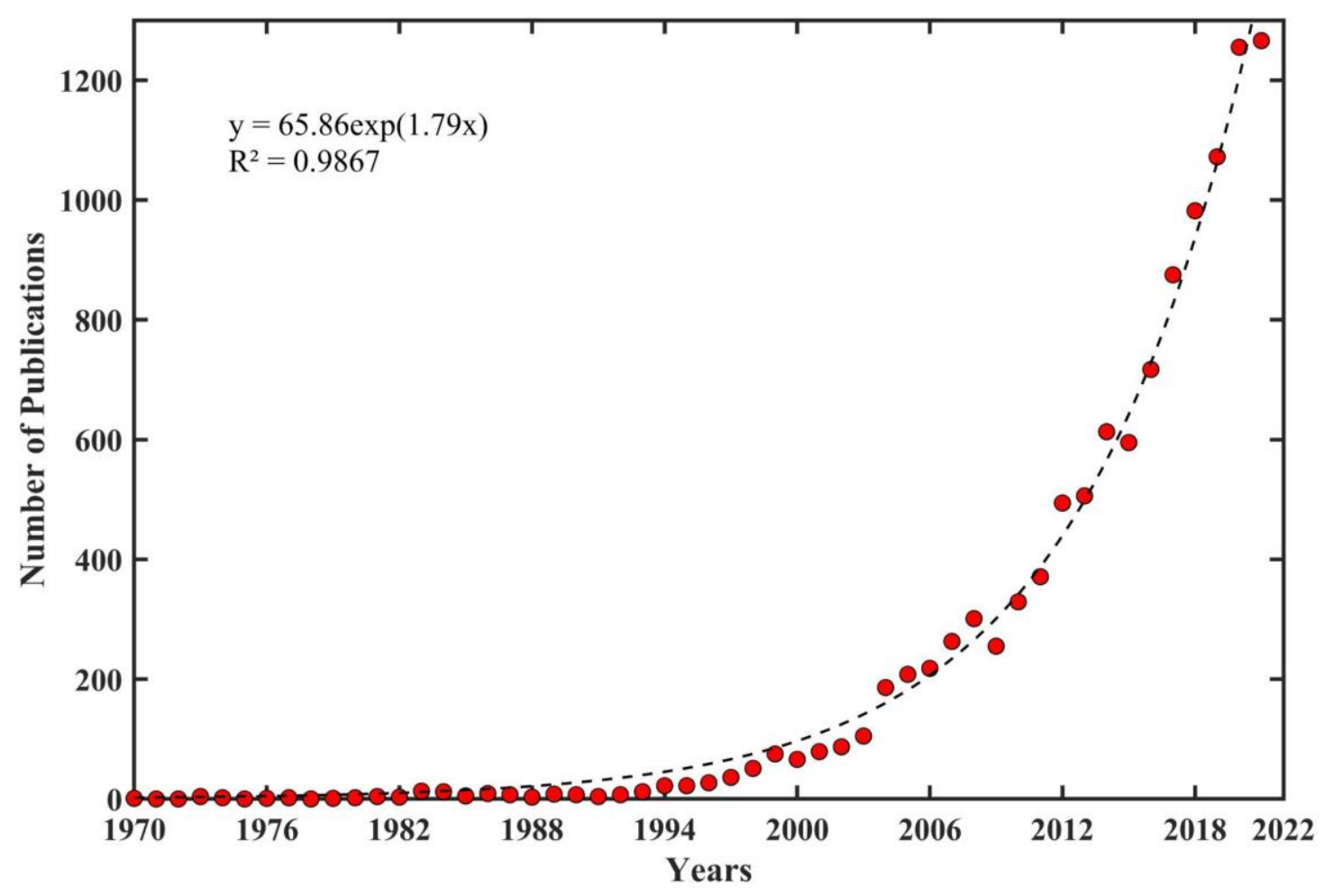

Adapted from LUZ et al. (2020).

For the specific case of the cement-based matrix, only recently the incorporation of NLFs has been considered. Figure 2 illustrates, according to Scopus (), the increase in publications related to "Natural fiber and cement composite".

Figure 2 - Publications per year for "Natural fiber and cement composite" according to Scopus database. 


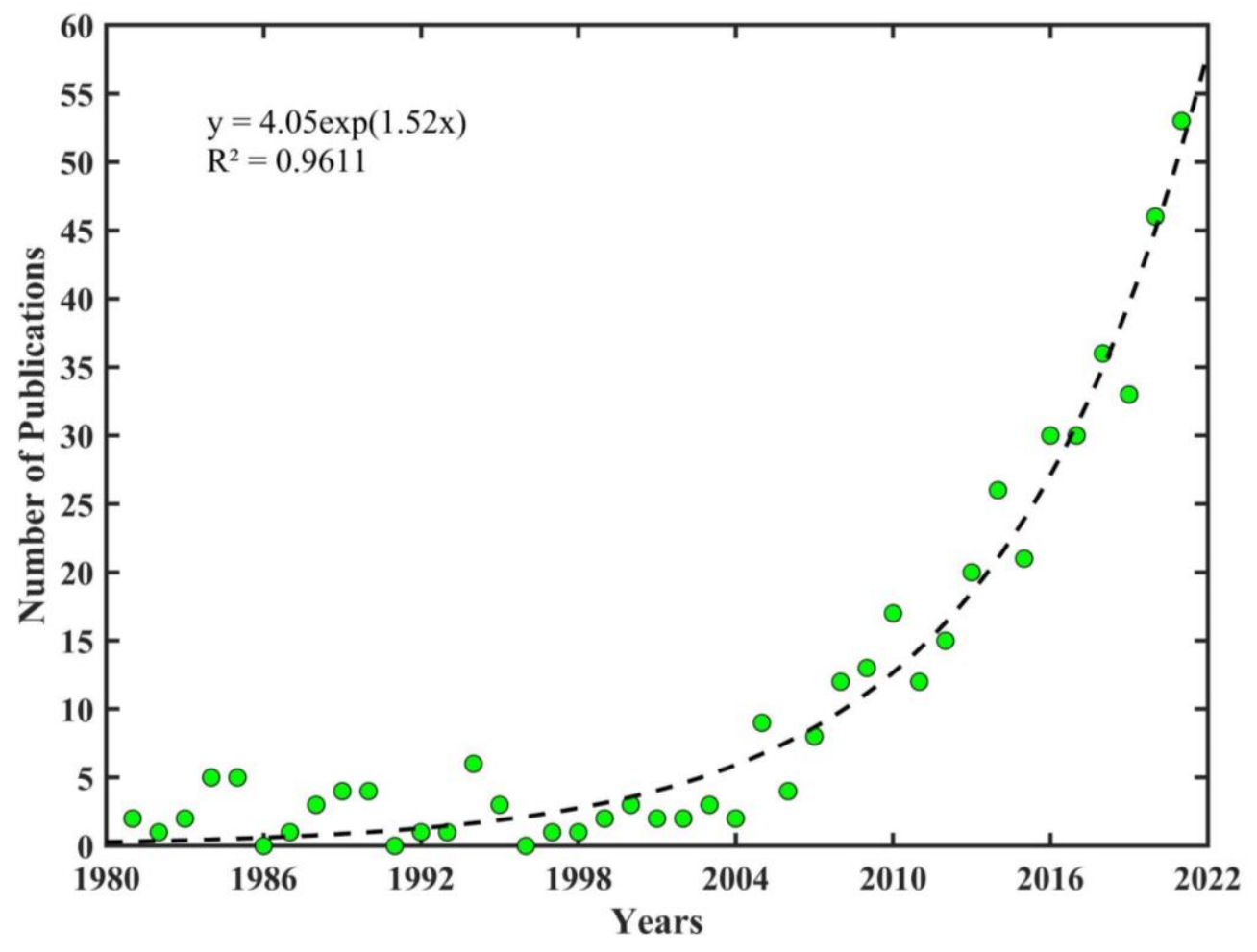

Scopus (2022).

The justification for this increasing interest in using NLFs in composites, demonstrated in Figures 1 and 2, might be explained by: (1) relatively lower density of natural fiber, which contributes to diminishing the weight of parts and structures; (ii) sustainable nature as compared with synthetic fibers in terms of biodegradability and recyclability; and (iii) the lower cost associated with less abrasion to process equipment (FARUK et al., 2012). On the other hand, NLFs exhibited heterogeneity in physical and mechanical properties. Owing to natural variations in chemical composition, diameter, and cultivation conditions (FRANCK, 2005; THAKUR; THAKUR; GUPTA, 2014). Another disadvantage is their hydrophilic nature, which hinders the fiber adhesion to a composite matrix (BLEDZKI; GASSAN, 1999; SAHEB; JOG, 1999). For this reason, surface pretreatments are performed before incorporation into the matrix to improve interfacial adhesion (MOHANTY; MISRA; DRZAL, 2002; MUKESH; GODARA, 2019).

Several NLFs have already been investigated as a possible reinforcement for cementbased composites (AZEVEDO et al., 2021; KESIKIDOU; STEFANIDOU, 2019; PICANÇO; GHAVAMI, 2008; PIMENTEL et al., 2016; SOLTAN et al., 2017; SOUZA; SOUZA; SILVA, 2020). These research works explored mainly the potential of curaua fiber and textile (PICANÇO; GHAVAMI, 2008; PIMENTEL et al., 2016; SOLTAN et al., 2017; SOUZA; SOUZA; SILVA, 2020) but more recently açaí fiber (AZEVEDO et al., 2021), as well as coir (coconut) and jute (KESIKIDOU; STEFANIDOU, 2019), were also investigated as reinforcement in mortars. In spite of these initiatives of using NLFs-incorporation into cement-based composites, numerous natural fibers are yet to be investigated. Among these, the stiff fiber extracted from the Brazilian 
palm tree piassava, illustrated in Figure 3, is by its rigid characteristic a promising reinforcement for cement-based composites.

Figure 3 - Piassava fiber: (a) bundle of fibers; and (b) SEM of single fiber

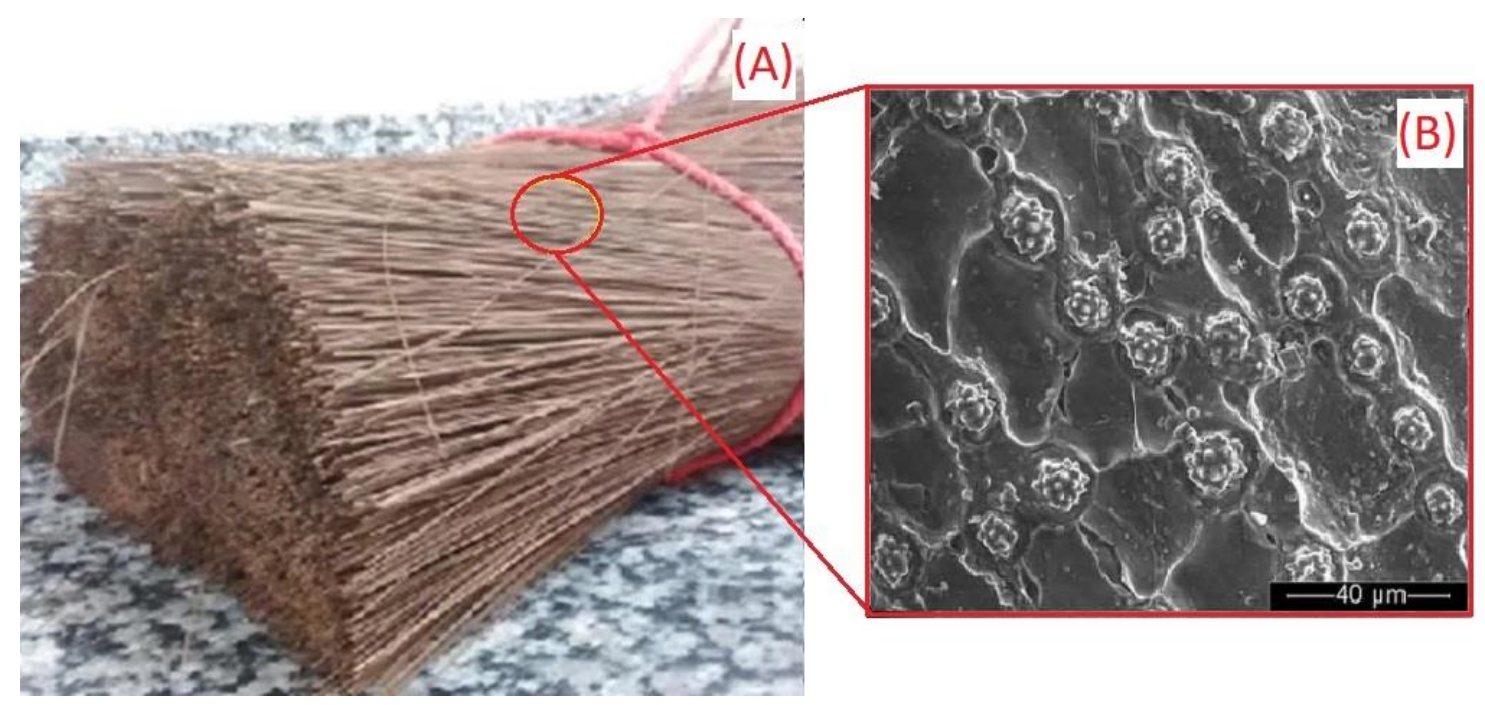

The chemical content of piassava fiber is indicated in Table 1.

Table 1 - Chemical content of piassava fiber

\begin{tabular}{cccccc}
\hline $\begin{array}{c}\text { Cellulose } \\
(\%)\end{array}$ & $\begin{array}{c}\text { Hemicellulose } \\
(\%)\end{array}$ & $\begin{array}{c}\text { Lignin } \\
(\%)\end{array}$ & $\begin{array}{c}\text { Ash } \\
(\%)\end{array}$ & $\begin{array}{c}\text { Extracts } \\
(\%)\end{array}$ & References \\
\hline $29-32$ & $25-26$ & $45-48$ & $1-2$ & $1-4$ & $\begin{array}{c}\text { SÁNCHEZ-SOTO, 2019; } \\
\text { LERTWATTANARUK; } \\
\text { SUNTIJTTO, 2015) }\end{array}$ \\
\hline
\end{tabular}

The relevant properties of piassava fibers for its reinforcement action are the mechanical presented in Table 2.

Table 2 - Mechanical properties of piassava fibers.

\begin{tabular}{ccccc}
\hline $\begin{array}{c}\text { Tensile } \\
\begin{array}{c}\text { Strength } \\
(\mathrm{MPa})\end{array}\end{array}$ & $\begin{array}{c}\text { Elastic } \\
\text { Modulus } \\
(\mathrm{GPa})\end{array}$ & $\begin{array}{c}\text { Elongation } \\
\text { at Break } \\
(\%)\end{array}$ & $\begin{array}{c}\text { Interval of } \\
\text { Diameters } \\
(\mu \mathrm{m})\end{array}$ & References \\
\hline $110-147$ & $1-5$ & $6-22$ & $250-700$ & $\begin{array}{c}\text { (ARCE; GARZÓN; SÁNCHEZ-SOTO, } \\
\text { 2019; LERTWATTANARUK; } \\
\text { SUNTIJTTO, 2015) }\end{array}$ \\
\hline
\end{tabular}


In view of the rigid characteristic of the piassava fibers, Figure 3, in association with mechanical properties, Table 2, the objective of the present work is to evaluate its application as reinforcement of fresh mortars intended for lining construction walls. Both untreated and $\mathrm{NaOH}$ treated piassava fibers added in amounts of 2 and $5 \mathrm{wt} \%$ to a common cement/lime/sand paste for mortar were evaluated for consistency, water retention, and incorporated volume of air.

\section{MATERIALS}

Piassava fibers shown in Figure 1 were supplied as a leftover from a brown industry in Campos dos Goytacazes, Rio de Janeiro, Brazil. The fibers were cleaned in runny water and dried on a stove at $60{ }^{\circ} \mathrm{C}$ for $24 \mathrm{~h}$. The mortar used as a matrix for the fiber incorporation was prepared using a standard mixture of ordinary Portland cement (OPC), lime, and sand in the proportion of 1:1:6, respectively. A Brazilian OPC type III (CPIII) was purchased in the local Campos dos Goytacazes specialized commercial store. The use of lime in mortar provides several advantages, which ensure greater durability under weather exposure in a tropical country like Brazil (29). The sand used as aggregate was naturally collected from the river and sieved to homogenize the granulometry.

\section{COMPOSITES PREPARATION}

Piassava fibers were added in relation to the mortar cementitious paste of 2 and $5 \mathrm{wt} \%$, both in their natural condition and alkali-treated with $\mathrm{NaOH}$.

\section{TECHNOLOGICAL TESTS}

Technological tests were carried out in the fresh state, just after composite preparation.

The consistency determination was performed by measuring the horizontal spreading of the composite paste on a slump table, which enabled the evaluation of the mortar's workability (LERTWATTANARUK; SUNTIJITTO, 2015).

The water retention was conducted in prismatic 40x40x160 mm specimens (ARCE; GARZÓN; SÁNCHEZ-SOTO, 2019). This allowed obtaining the capacity to fill the internal pores of the mortar with water.

The content of incorporated air was measured by using the pressiometric method, which indicates the volume of air in the mortar. Together with the water retention, it gives the capacity 
of the mortar to retain and suction water from the applied substrate (AZEVEDO et al., 2020, 2019; FEDIUK et al., 2017).

\section{RESULTS AND DISCUSSION}

Table 3 presents the results of the technological tests in terms of the corresponding parameters.

Table 3 - Technological fresh state parameters for mortars added with piassava fibers.

\begin{tabular}{ccccc}
\hline Composition & $\begin{array}{c}\text { Consistency } \\
(\mathbf{m m})\end{array}$ & $\begin{array}{c}\text { Mass density in } \\
\text { fresh state }\left(\mathbf{g} / \mathbf{c m}^{\mathbf{3}}\right)\end{array}$ & $\begin{array}{c}\text { Water } \\
\text { Retention (\%) }\end{array}$ & $\begin{array}{c}\text { Incorporated } \\
\text { Air (\%) }\end{array}$ \\
\hline Reference & 264.2 & 2 & 95.9 & 7.5 \\
2\% Untreated fiber & 257.6 & 1.95 & 94.96 & 8.1 \\
2\% Treated fiber & 260.2 & 1.97 & 95.37 & 7.9 \\
$5 \%$ Untreated fiber & 246.4 & 1.89 & 93.8 & 8.7 \\
$5 \%$ Treated fiber & 248.9 & 1.95 & 94.46 & 8.3 \\
\hline
\end{tabular}

Based on the results presented in Tabel 3, the corresponding graphical interpretations are shown in Figures 4 to 7. As for consistency results, in Figure 4, only a slight decrease occurred with the incorporation of piassava fiber. Moreover, practically no change occurred as a consequence of fiber $\mathrm{NaOH}$ treatment. In principle, one may conclude that the mortar workability is not significantly affected by the addition of piassava fibers up to $5 \mathrm{wt} \%$.

Figure 4 - Consistency results with piassava incorporation. 


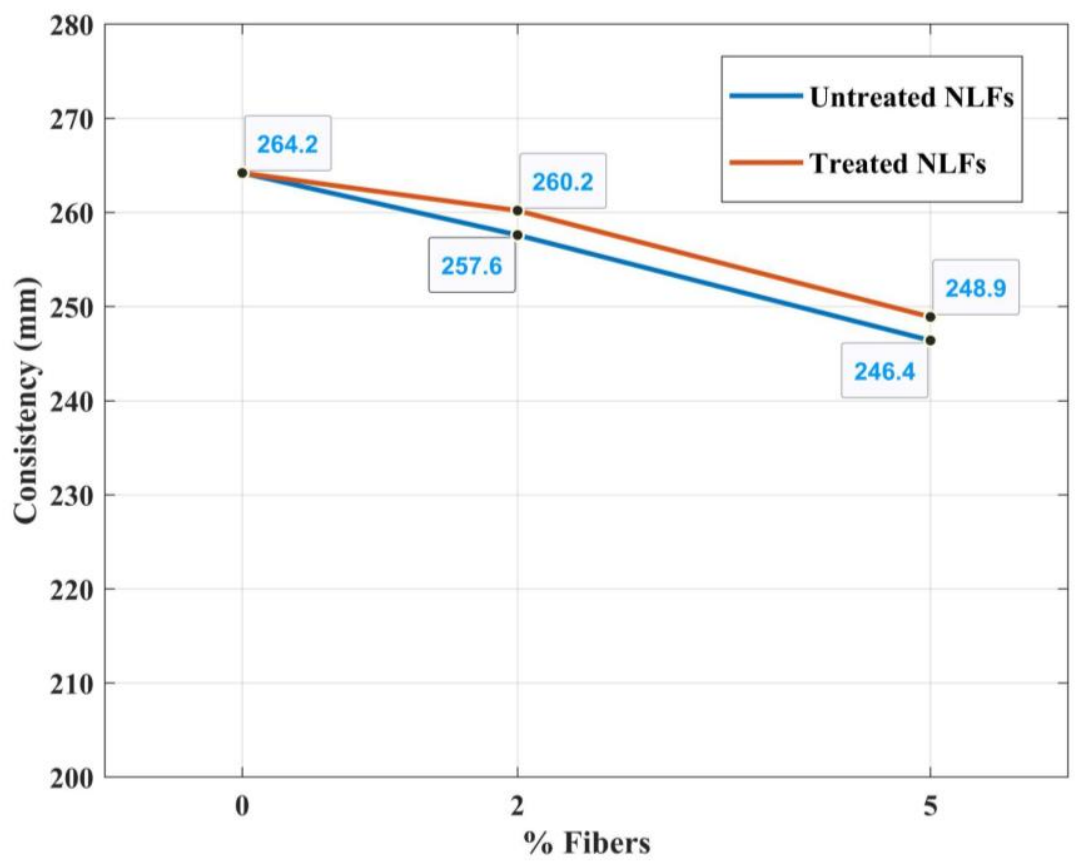

Regarding the relative volume of incorporated air in Figure 5, there is a moderate increase from the plain mortar ( $0 \%$ fibers) with $7.5 \%$ to $8.3-8.5 \%$ for the $5 \mathrm{wt} \%$ piassavas added mortar. It is also important to note that air incorporation was sensibly higher for the mortar added with $\mathrm{NaOH}$ treated piassava fiber. This can be attributed to the effective generation of fiber surface open porosity due to the attack by alkali treatment.

Figure 5 - Results obtained with the incorporation of air in the composite.

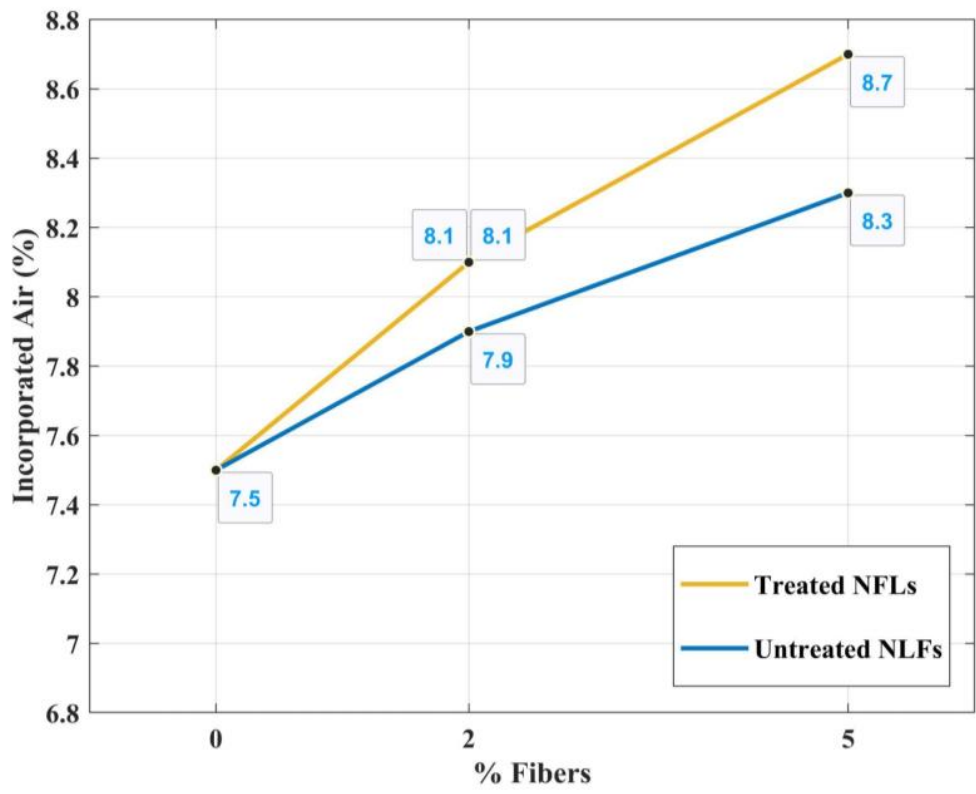


The density in fresh state curves shown in Figure 6 displays the expected tendency to slightly decrease owing to the relatively lower density of the piassava fibers. As expected, this decrease in mass density is more effective in mortars with $\mathrm{N}_{2} \mathrm{OH}$ treated fibers which tend to lose more wax and lignin.

Figure 6 - Mass density in a fresh state.

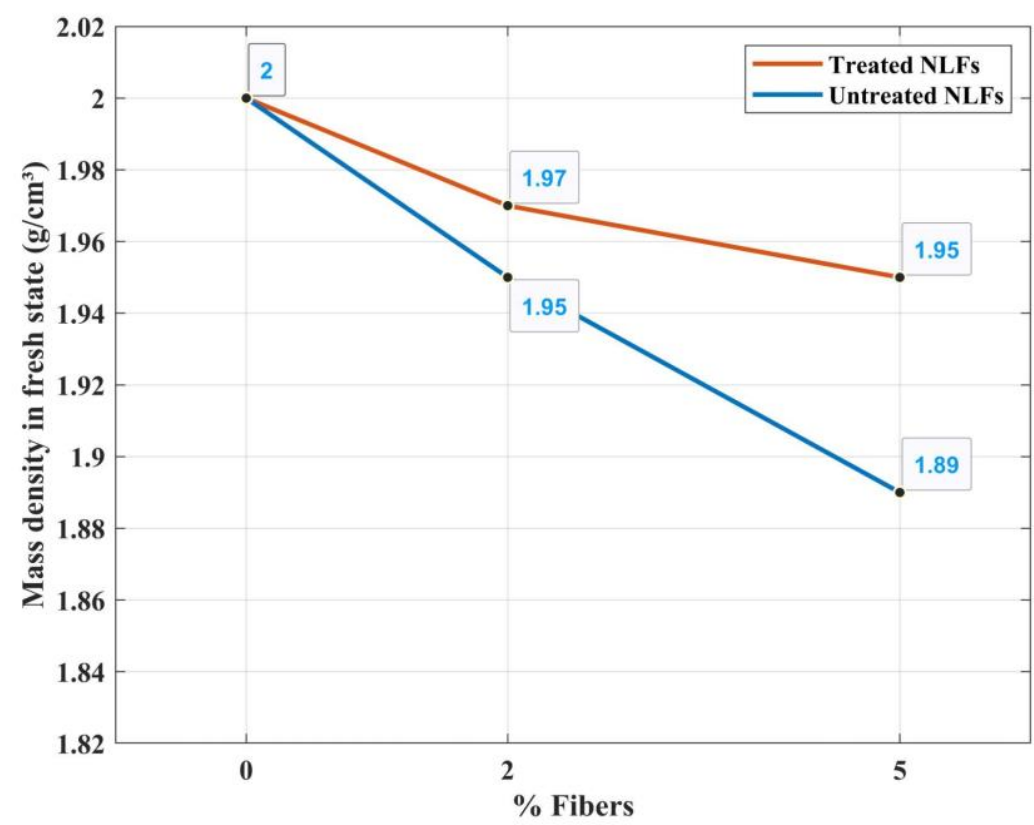

Finally, Figure 7 shows the variation of water retention with the addition of piassava fiber to the mortar. Contrary to what one would expect, the presence of piassava fiber caused a decrease in water retention associated with both untreated and treated fibers. A possible explanation is that the piassava fiber promotes a better adhesion with the mortar's OPC as previously suggested by MARVILA et al. (2020) for açaí added mortars. In the particular case of piassava fibers, the surface $\mathrm{SiO}_{2}$ protrusions, Figure 1(b), might be responsible for the improved interfacial bonding with the mortar's cement past as happens with polymer matrix.

Figure 7 - Water retention with the addition of piassava fiber to the mortar. 


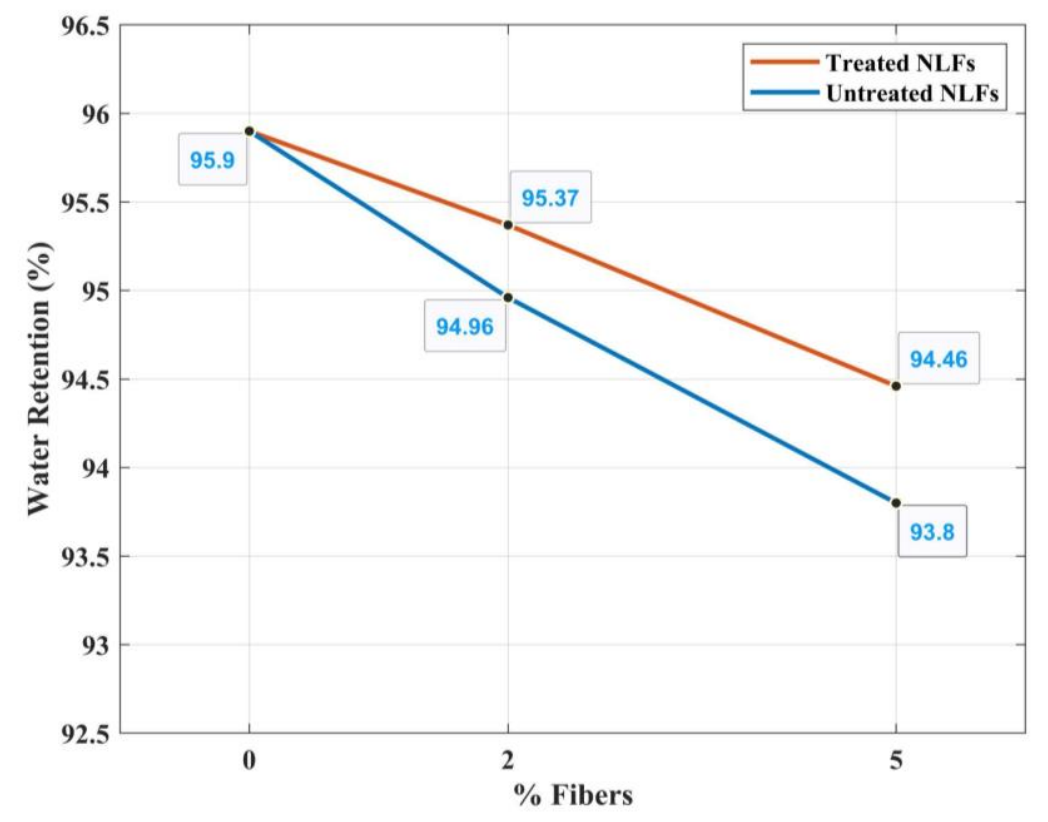

\section{CONCLUSIONS}

The preliminary technical results of piassava fibers incorporated mortar in the fresh state permit to draw the following conclusions:

- The mortar consistency is only slightly reduced without practically no effect due to the piassava $\mathrm{NaOH}$ treatment.

- The content of incorporated air is increased with greater change associated with $\mathrm{NaOH}$ treated piassava fibers. This is attributed to a higher amount of surface open porosity generated by the alkali attack.

- The mass density in the fresh state is reduced with the addition of piassava fibers owing to their relatively lower density.

- The addition of piassava fibers caused a decrease in water retention despite the hydrophobicity of these natural lignocellulosic fibers. It is suggested that the piassava fibers promote better adhesion to the mortar's cement paste due to their characteristics of surface protrusion.

- Based on these technical findings, it is also possible to conclude that fabrication of mortars added up to $5 \mathrm{wt} \%$ of piassava fibers offers a novel material for wall lining in building material. 


\section{ACKNOWLEDGEMENTS}

The authors thank the Brazilian supporting agencies: CAPES, CNPQ, and FAPERJ for funding and scholarship.

\section{REFERENCES}

AISYAH, H. A. et al. A Comprehensive Review on Advanced Sustainable Woven Natural Fibre Polymer Composites. Polymers, v. 13, n. 3, p. 471, jan. 2021.

ARCE, C.; GARZÓN, E.; SÁNCHEZ-SOTO, P. J. Phyllite clays as raw materials replacing cement in mortars: Properties of new impermeabilizing mortars.

Construction and Building Materials, v. 224, p. 348-358, 10 nov. 2019.

AZEVEDO, A. R. et al. Development of mortar for laying and coating with pineapple fibers. Revista Brasileira de Engenharia Agrícola e Ambiental, v. 24, n. 3, p. 187193, mar. 2020.

AZEVEDO, A. R. G. et al. Effect of Granite Residue Incorporation on the Behavior of Mortars. Materials, v. 12, n. 9, p. 1449, jan. 2019.

AZEVEDO, A. R. G. et al. Technological performance of açaí natural fibre reinforced cement-based mortars. Journal of Building Engineering, v. 33, p. 101675, 1 jan. 2021.

BENZAIT, Z.; TRABZON, L. A review of recent research on materials used in polymer-matrix composites for body armor application. Journal of Composite Materials, v. 52, n. 23, p. 3241-3263, Setembro 2018.

BLEDZKI, A. K.; GASSAN, J. Composites reinforced with cellulose based fibres. Progress in Polymer Science, v. 24, n. 2, p. 221-274, Maio 1999.

DUNNE, R. et al. A review of natural fibres, their sustainability and automotive applications. Journal of Reinforced Plastics and Composites, v. 35, n. 13, p. 10411050, 1 jul. 2016.

FARUK, O. et al. Biocomposites reinforced with natural fibers: 2000-2010. Progress in Polymer Science, Topical Issue on Polymeric Biomaterials. v. 37, n. 11, p. 15521596, 1 nov. 2012.

FARUK, O. et al. Progress Report on Natural Fiber Reinforced Composites.

Macromolecular Materials and Engineering, v. 299, n. 1, p. 9-26, 2014.

FEDIUK, R. S. et al. Using thermal power plants waste for building materials. IOP Conference Series. Earth and Environmental Science, v. 87, n. 9, out. 2017.

FRANCK, R. R. Bast and Other Plant Fibres. Boca Raton, FL, USA: CRC Press, 2005. 
KARIMAH, A. et al. A review on natural fibers for development of eco-friendly biocomposite: characteristics, and utilizations. Journal of Materials Research and Technology, v. 13, p. 2442-2458, 1 jul. 2021.

KESIKIDOU, F.; STEFANIDOU, M. Natural fiber-reinforced mortars. Journal of Building Engineering, v. 25, p. 100786, Setembro 2019.

KUMAR, R. et al. Industrial applications of natural fibre-reinforced polymer composites - challenges and opportunities. International Journal of Sustainable Engineering, v. 12, n. 3, p. 212-220, Maio 2019.

LERTWATTANARUK, P.; SUNTIJITTO, A. Properties of natural fiber cement materials containing coconut coir and oil palm fibers for residential building applications. Construction and Building Materials, v. 94, p. 664-669, Setembro 2015.

LI, M. et al. Recent advancements of plant-based natural fiber-reinforced composites and their applications. Composites Part B: Engineering, v. 200, p. 108254, 1 nov. 2020 .

LUZ, F. S. et al. Graphene-Incorporated Natural Fiber Polymer Composites: A First Overview. Polymers, v. 12, n. 7, p. 1601, jul. 2020.

MARVILA, M. T. et al. Durability of coating mortars containing açaí fibers. Case Studies in Construction Materials, v. 13, p. e00406, Dezembro 2020.

MOHANTY, A. K.; MISRA, M.; DRZAL, L. T. Sustainable Bio-Composites from Renewable Resources: Opportunities and Challenges in the Green Materials World. Journal of Polymers and the Environment, v. 10, n. 1, p. 19-26, 1 abr. 2002.

MONTEIRO, S. N. et al. Natural-fiber polymer-matrix composites: Cheaper, tougher, and environmentally friendly. JOM, v. 61, n. 1, p. 17-22, 1 jan. 2009.

MONTEIRO, S. N. et al. Natural Lignocellulosic Fibers as Engineering Materials-An Overview. Metallurgical and Materials Transactions A, v. 42, n. 10, p. 2963, 15 jul. 2011.

MUKESH; GODARA, S. S. Effect of chemical modification of fiber surface on natural fiber composites: A review. Materials Today: Proceedings, 9th International Conference of Materials Processing and Characterization, ICMPC-2019. v. 18, p. 34283434, 1 jan. 2019.

PICANÇO, M. DE S.; GHAVAMI, K. Comportamento à compressão de argamassas reforçadas com fibras vegetais da Amazônia. Rem: Revista Escola de Minas, v. 61, n. 1, p. 13-18, mar. 2008.

PICKERING, K. L.; EFENDY, M. G. A.; LE, T. M. A review of recent developments in natural fibre composites and their mechanical performance. Composites Part A: Applied Science and Manufacturing, Special Issue on Biocomposites. v. 83, p. 98112, Abril 2016. 
PIMENTEL, M. G. et al. Resposta à flexão e análise de tenacidade de argamassas reforçadas com fibra de Curauá. Matéria (Rio de Janeiro), v. 21, p. 18-26, mar. 2016.

POTLURI, R.; CHAITANYA KRISHNA, N. Potential and Applications of Green Composites in Industrial Space. Materials Today: Proceedings, 2nd International Conference on Materials Manufacturing and Modelling, ICMMM - 2019, VIT University, Vellore, 29th - 31st March 2019. v. 22, p. 2041-2048, 1 jan. 2020.

SAHEB, D. N.; JOG, J. P. Natural fiber polymer composites: A review. Advances in Polymer Technology, v. 18, n. 4, p. 351-363, 1999.

SANJAY, M. R. et al. Characterization and properties of natural fiber polymer composites: A comprehensive review. Journal of Cleaner Production, v. 172, p. 566581, 20 jan. 2018.

SCOPUS: Available online: <www.scopus.com/search/form.uri\#basic>. Accessed on 25 jan. 2022.

SOLTAN, D. G. et al. Introducing a curauá fiber reinforced cement-based composite with strain-hardening behavior. Industrial Crops and Products, v. 103, p. 1-12, Setembro 2017.

SOUZA, L. O. DE; SOUZA, L. M. S. DE; SILVA, F. DE A. Mechanical autogenous recovery and crack sealing of natural curauá textile reinforced concrete. Construction and Building Materials, v. 235, p. 117476, Fevereiro 2020.

THAKUR, V. K.; THAKUR, M. K.; GUPTA, R. K. Review: Raw Natural Fiber-Based Polymer Composites. International Journal of Polymer Analysis and

Characterization, v. 19, n. 3, p. 256-271, Abril 2014.

THYAVIHALLI GIRIJAPPA, Y. G. et al. Natural Fibers as Sustainable and Renewable Resource for Development of Eco-Friendly Composites: A Comprehensive Review.

Frontiers in Materials, v. 6, 2019.

VIGNESHWARAN, S. et al. Recent advancement in the natural fiber polymer composites: A comprehensive review. Journal of Cleaner Production, v. 277, p. 124109, Dezembro 2020.

ZHANG, Z. et al. High performances of plant fiber reinforced composites-A new insight from hierarchical microstructures. Composites Science and Technology, v. 194, p. 108151, 7 jul. 2020.

\section{Recebido em: 10/01/2022}

Aprovado em: 12/02/2022 